\title{
REDES DE CLIENTELA, FUNCIONÁRIOS RÉGIOS E APROPRIAÇÃO DE RENDA NO IMPÉRIO PORTUGUÊS (SÉCULOS XVI-XVIII)
}

\author{
Edval de Souza Barros \\ Universidade Federal do Rio de Janeiro
}

\begin{abstract}
RESUMO
Este artigo procura relacionar a lógica clientelista às práticas políticas e jurídicas em sociedades do Antigo Regime. Defende a hipótese de que tal relação circunscreve as possibilidades de acesso às rendas geradas pelos circuitos mercantis, repercutindo sobre as decisões da Coroa, entendidas como estratégias de intervenção pontual em contextos de negociação e conflito.
\end{abstract}

PALAVRAS-CHAVE: redes de clientela; Império Português; economia; política; direito.

\section{I. À GUISA DE INTRODUÇÃO}

As redes de clientela são os instrumentos que permitem às pessoas das mais diferentes posições sociais garantir algum grau de segurança frente à instabilidade do século. Essa afirmação pode ser generalizada para várias sociedades e épocas, e não se limita às do Antigo Regime ${ }^{2}$. Como tudo o mais, entretanto, possuem uma história. Suas diferentes configurações - com os objetivos e estratégias correspondentes - são conformadas pelas múltiplas dimensões que mobilizam, tratando-se, em certo sentido, do que Marcel Mauss denominaria de um fato social total (MAUSS, 1974, p. 4348). Como uma forma mais geral de relação social, elas atravessam espaços variados de interação, condensando as categorias culturais próprias a

\footnotetext{
1 Gostaria de agradeceràs criteriosas e generosas contribuições dos dois parecenistas anônimos da Revista de Sociologia e Política, que ajudarama polir a versão original. Obviamente, assumo inteira responsabilidade pelo resultado final.

2 Podemos encontrálas na Roma antiga ou nas cidades italianas do século XIV, e a sociologia e a ciência política contemporâneas, interessadas nosentraves ao processo de modernização em países de terceiro-mundo ou subdesenvolvidos, consumiram bastante tinta tratando do assunto (EISENSTADT \& RONIGER, 1980). Dois trabalhos atestam, para o Brasil, o interesse que desperta junto aos historiadores (LEWN, 1993; GRAHAM, 1997). Mas é na historiografia dedicadaao estudo das relações políticas que caracterizaram oEstado absolutista que se concentram atualmente, o maior volume de trabalhos, na esteira da obra de Elias (1995). Para uma bibliografia sobre o assunto, cf. Millán (1994).
}

cada um deles em um todo mais ou menos coerente. Seu estudo, portanto, demanda conhecimentos que se costuma atribuir a áreas bem delimitadas, como as da cultura, do direito, da política e da economia. Talvez não haja melhor prova do equívoco de isolá-las em espaços estanques do que os problemas que as redes de clientela apresentam ao pesquisador.

As dificuldades que sua análise oferece derivam exatamente da necessidade de se recorrer a todas essas áreas simultaneamente. A Antropologia, nesse sentido, pode fornecer modelos que permitam lidar com a compartimentação típica da Sociologia ou da História. Mas deve-se ter em mente que o próprio objeto vê-se transformado pela multiplicação dos espaços de sociabilidade, especialmente na Europa a partir do século XIII (GENET, 1992; 1997; ELIAS, 1993; WEBER, 1998), pari passu ao processo de constituição do Estado moderno, que crescentemente passou a conformá-los. Cada um dos saberes mencionados selecionou seu objeto a partir desse processo, isolando-o e impedindo, desse modo, a identificação de fenômenos sociais que perpassassem suas respectivas áreas de conhecimento sem por elas ser contido. Dentre eles, as redes de interação social viram-se eclipsadas, já que não se reduziam a nenhuma esfera específica, mas constituíam seu arcabouço ${ }^{3}$. Como um tipo específico daquele fenômeno - das redes de intera-

\footnotetext{
3 Ou, em outras palavras, instituições supõem interação, mas não o contrário. A bibliografia sobre as redes de interação
} 
ção social -, as redes de clientela padeceram da mesma sina. Mas, na medida em que não podem ser pensadas dissociadas dos lugares que ocupam, dos valores pelos quais pautam suas ações e dos recursos que são capazes de mobilizar, os processos de diferenciação social e institucional multiplicam suas configurações, hierarquizando os espaços e os agentes que dela participam ${ }^{4}$. Os estudos antropológicos, se de grande utilidade, não se mostram de todo adequados ao tema em questão - apesar de algumas contribuições dessa área para a análise dos fenômenos políticos e do Estado (GEERTZ, 1991) -, por tratar de sociedades cuja afinidade com a história ocidental torna-se cada vez menor à medida que avançamos no tempo. Sua maior contribuição advém do aporte metodológico que, com as devidas adaptações, passou a ser incorporado ao arsenal de historiadores cada vez mais sensíveis ao problema geral das relações entre o que se convencionou chamar de microfenômenos e macroprocessos.

Uma seqüência bastante conhecida de fenômenos históricos afastou crescentemente as instituições e a sociedade européias das demais, como, por exemplo, o direito romano e a difusão do cristianismo, duas das principais balizas da chamada civilização ocidental ${ }^{5}$. Sobre tais processos debruçaram-se os clássicos da Sociologia na fase pioneira da disciplina, e embora seus praticantes procurassem, durante algum tempo, desvincular-se da história, a ênfase nas relações entre processos históricos e fenômenos sociais voltou a emergir nos anos sessenta, ocupando

social, ou "social networks" é vasta. Para uma leitura que as propõe como paradigma sociológico, ver Tumer (1988); para uma discussão das questões metodológicas que suscita, cf. Emirbayere Goodwin (1994).

4 As redes de clientela surgiram no bojo do processo mais geral de diferenciação social, pois as relações entre patronos - ou benfeitores -, intermediários e clientes supõem um acesso desigual a algumtipo de bem, e, mais do que isso, uma institucionalização dessa desigualdade. Desse modo, é um fenômeno afim ao surgimento das linhagens e, posteriormente, doEstado. Mas, se como processo mais geral as redes de interação social verticalizadas podem ser objeto da Antropologia, a complexa divisão social que caracteriza as sociedades modemas demandam outros arsenais metodológicos.

5 Sobre aimportância do cristianismo e do papel que exerceu, a partir do século XIII, no processo de releitura do direito romano, ver Dumont (1985). Quanto à idéia de seqüência histónica como uma variável intrínseca aos processos de trans formação social, ver Gellner (1988, p. 16-20). espaço considerável na agenda dos sociólogos desde então (MOORE JR., 1983; SKOCPOL, 1985; TILLY, 1996; DOWNING, 1992; ERTMAN, 1997) $)^{6}$.

A sociologia histórica tem-se dedicado principalmente a retomar a agenda weberiana, dando particular atenção aos processos que resultaram na formação do Estado moderno e das formas sociais que lhe são próprias. Entre os autores de língua inglesa, tal agenda passou igualmente a influenciar os historiadores, e questões como a formação dos aparatos burocráticos, a influência da guerra, o financiamento das crescentes obrigações do Estado e a resistência oferecida da parte dos corpos constituídos contra imposições fiscais ou reduções de jurisdição deram origem a um crescente número de trabalhos, todos visando à comparação entre as trajetórias singulares que caracterizaram a formação dos Estados modernos (BEIK, 1985; BREWER, 1989; GENET, 1992; T'HART, 1993; BONNEY, 1995; 1999; PARKER, 1996).

$\mathrm{O}$ enfoque propriamente sociológico de tais abordagens, mesmo quando levadas a cabo por historiadores profissionais, priorizou, nos estudos de caso, macroprocessos cujas implicações teóricas não escaparam a outras correntes historiográficas que se debruçavam sobre as mesmas questões, mas enfatizavam outras premissas ou ordens de escala ${ }^{7}$. Enquanto os primeiros identificam o Estado como a questão, o sujeito e o telos para o qual convergiam todas as ações, os demais denunciam as implicações teleológicas, e, conseqüentemente, anacrônicas, de uma leitura demasiadamente linear. Além disso, defendem a necessidade de se levar em conta a microdinâmica social encoberta por modelos que dão excessiva ênfase aos resultados, sem levar em conta a complexa interação da qual derivavam. Suas críticas podem ser resumidas a duas:

1) A ênfase excessiva na continuidade do processo de consolidação do Estado moder-

\footnotetext{
6 Paraumbalanço das principais matrizes teónicas do campo, ver Skocpol (1984).

7 O que nãoquerdizerque perdessemde vistaa singularidade dos ditos casos; pelo contrário. Masé o pano de fundo mais geral sobre o qual projetamos ditos "processos" que os tomam passíveis de crítica, posto que manipulammodelos sociológicos que mobilizam tanto categorias weberianas (BREWER, 1989, T'HART, 1993) quanto marxistas (BEIK, 1985) capazes de situá-los como "variantes" de modelos mais gerais (burocratização versus patrimonialismo, por exemplo).
} 
no, a partir de um modelo centro-periferia, deixa de lado as interações entre os diferentes agentes em contextos circunscritos. A micro-história, ao priorizar o nível local - em função de exigências metodológicas -, procura identificar aí instâncias de ordem diversa e reconstituir a natureza de suas relações. Portanto a escala não delimita o grau de abrangência das conclusões, sendo as estratégias e relações no nível "micro" de grande importância para a compreensão de processos que extrapolem esta dimensão;

2) A natureza específica das relações políticas, em sociedades do Antigo Regime, não se pautou pelo modelo de subordinação dos indivíduos a um único poder soberano, fundado sobre o direito positivo, e seu estudo deve levar em conta a coexistência de direitos, jurisdições e corpos autônomos e distintos, dos quais a Coroa era apenas mais um. Desse modo, deve-se evitar o recurso a um modelo dicotômico que situa os poderes e competências no pólo estatal, expropriando as demais instâncias da capacidade de ação legítima e efetiva.

A primeira crítica deriva principalmente dos trabalhos realizados pela corrente oriunda da micro-história italiana e de seus adeptos franceses, influenciados em parte pela sociologia interacionista (LEVI, 1989; REVEL, 1989; 1998). A segunda, por sua vez, procede da história do direito, principalmente alemã, italiana e espanhola, que dá particular ênfase à natureza corporativa das sociedades do Antigo Regime, procurando desvincular seu estudo do direito jusnaturalista póssetecentos (HESPANHA, 1984; SCHAUB, 1995). As duas, contudo, fazem coro ao enfatizarem a não-linearidade e a não-sistematicidade dos processos que resultaram no Estado moderno europeu, posto que os agentes envolvidos manipulavam modelos alternativos de institucionalização de poder e de ação política. Por vezes, negociação e acomodação permitiam mudanças graduais sem rupturas perceptíveis. Mas os usos diferenciados das instâncias de poder, ou a defesa de instâncias alternativas, podiam levar ao conflito. Assim, tanto uma quanto outra corrente historiográfica procura resgatar os diferentes modelos e práticas próprios àquela sociedade, dentre os quais apenas alguns foram incorporados ao resultado final. E mesmo quando a negociação cedia lugar ao choque aberto, a nova configuração só assumia contornos definidos após a resolução dos conflitos $e$ em sua decorrência.

Ambas, igualmente, convergem na relativização do ritmo e da intensidade com que os poderes centrais eram capazes de efetivamente atuar junto às instâncias locais ou aos poderes intermediários, posto que em grande parte deles dependiam para a consecução de uma série de objetivos. As diferentes dinâmicas ditavam, por sua vez, múltiplos resultados, fechando algumas alternativas e franqueando outras. As várias combinações possíveis refletiam-se no cenário das disputas internacionais, tornando-se de grande relevância para se entender os desníveis de poder entre Estados concorrentes.

Esse ponto é particularmente enfatizado pelos proponentes da micro-história. Apesar das divergências teóricas que perpassam essa corrente - o debate em torno do papel da escala para a definição de relações causais pertinentes (REVEL, 1998, p. 13-14) -, uma abordagem que procure preservar o caráter aberto, ou imponderável, das conseqüências de cada intervenção particular num dado momento acabará colocando-se ao lado daqueles que afirmam que a escala não é apenas um recurso metodológico, mas um elemento inerente aos próprios fenômenos estudados. Não se trata, portanto, da escolha entre escalas diferentes, adequadas a este ou aquele fenômeno ou processo singular. $\mathrm{O}$ emprego de microescalas redefine as características do próprio fenômeno, qualquer que seja - posto que todos supõem interações específicas entre agentes capazes de mobilizar estratégias que lhes sejam compatíveis. Mais do que isso, tais escolhas estratégicas redefinem o processo, entendido como a interrelação entre diferentes contextos em constante mutação. A busca de um eixo mediador capaz de compatibilizá-los - a opção pela macroescala, que parte de uma categoria pré-definida para encontrar na multiplicidade de fenômenos sociais uma confirmação da sua maior ou menor realidade ou adequação - torna as ações dos sujeitos envolvidos unidimensionais, à medida que se vê forçada a descartar a coexistência de diferentes objetivos em um mesmo contexto de interação ${ }^{8}$. A idéia de

\footnotetext{
8 De fato, descarta a própria noção de contexto. Embora implícita em qualquer análise que procure singularizar algum fenômeno social, isso apenas é possivel a partir de deslocamentos metafóricos que imputamàs categorias de análise a capacidade de agir (v. g. Estado, mercado, classe
} 
que seja possível empregar ambas as abordagens simultaneamente pressupõe que a microescala acrescenta "detalhes", enriquecendo o panorama cujas balizas principais são definidas por macroprocessos. A tentativa de torná-las "recursos metodológicos legítimos", ao gosto do freguês, comporta implícita a aceitação de uma descontinuidade do social que a abordagem micro-histórica nega veementemente.

Ao cruzarem espaços que se supõem estanques, as redes de clientela tornam-se um objeto mais do que adequado ao enfoque micro-histórico. Existindo em função de escolhas que procuram potencializar os recursos à disposição de um dado agente, em contextos específicos e mutáveis ao sabor de configurações que elas mesmas constituem, seu estudo põe à prova os pressupostos metodológicos da sociologia histórica. Por outro lado, a forma como se constituem, os objetivos que buscam alcançar e as representações que mobilizam, ao variarem no espaço e no tempo, exigem, para sua compreensão adequada, demarcações históricas bem definidas. Em sociedades do Antigo Regime, é todo um conjunto de categorias demasiado próximas, mas na verdade radicalmente distintas, que se apresentam à análise. As considerações que se seguem procuram ter em conta essas duas dimensões, uma metodológica (a abordagem micro-histórica) e outra teórica (a teoria corporativa do direito), com vistas a identificar algumas de suas características e relacioná-las com as transformações por que passa a sociedade portuguesa na Europa e no Ultramar no período compreendido, grosso modo, entre a passagem do século XV para o XVI e meados do século XVIII.

Para tanto, enfocaremos a análise em três momentos que permitam visualizar a pluralidade de dimensões que o objeto tratado (as redes de clientela em sociedades do Antigo Regime) condensam. Cada momento priorizará uma dimensão específica: o das representações identitárias (as

etc.), já que a categoria de contexto não pode ser dissociada da categoria afim de escolha (estratégica). E, nesse sentido, apenas pessoas escolheme agememfunção dessas escolhas Comisso não se pretende cair nailusão de que asociedadeé asomadas ações individuais, masconsideramos que as pessoas recorrem a um leque bastante variado de identidades, ou papéis, no decurso de suas vidas. De certa forma, aquelas categorias sociológicas não passariam da abstração dessas identidades, elas mesmas, por sua vez, constituídas historicamente (REVEL, 1998, p. 26-27). relações entre nobreza e Coroa), o da legitimidade social de arranjos informais (comparação entre comerciantes e aventureiros no Estado da Índia) e o da organização jurídico-política (as redes de clientela e sua relação com a concepção corporativista da sociedade). O quarto momento ilustrará como todas essas dimensões estão presentes simultaneamente num contexto específico de interação: a disputa pela apropriação de renda a partir da inserção dos agentes em relações verticalizadas e o uso que estes últimos dão às prerrogativas correspondentes que lhes conferem legitimidade. Algumas considerações ao final retomarão a discussão sobre a importância da microescala para a abordagem de processos de mudança social em contextos sócio-históricos circunscritos a partir dos exemplos acima mencionados.

\section{CORTE E IMPÉRIO ULTRAMARINO NO SÉCULO XVI}

Ninguém questiona a fragilidade do Império Português frente aos seus concorrentes ultramarinos a partir do primeiro quarto do século XVII. Assim que a Inglaterra e os Países Baixos começaram a pressionar a capacidade defensiva lusitana no além-mar, a escassez de meios humanos e materiais tornou-se patente. Sua longevidade só pode ser explicada pelo recurso sistemático à diplomacia, que garantiu à Coroa portuguesa o reconhecimento inglês e neerlandês do status quo ultramarino frente às ameaças continental e marítima da Espanha e da França. Como se sabe, esse reconhecimento não se fez sem concessões substanciais e sem o alijamento português da Ásia (NOVAIS, 1986, p. 17-43). Mesmo sofrendo duro golpe com a perda dos entrepostos asiáticos, a Coroa portuguesa preservou amplos recursos, na América e na África. Esses recursos continuaram sendo canalizados para Lisboa, financiando as necessidades da Coroa, suplementando a renda da fidalguia portuguesa e garantindo o ganha-pão de numerosos funcionários régios e de suas famílias, por meio da concessão de cargos, pensões, comendas e emolumentos. Se as fronteiras do império passaram então a ser garantidas pela diplomacia, a apropriação e a distribuição de recursos que financiavam a existência material daquela entidade político-territorial dependiam de outros fatores.

Conhecemos os traços gerais que permitem definir o Império Português como um sistema comercial construído ao redor de um aparato 
burocrático ancien régime (SCHWARTZ, 1979, p. 177). Mas ambas as dimensões, a comercial e a administrativa, apresentaram grande diversidade, proveniente das necessidades de adequação aos vários espaços sob jurisdição portuguesa. Tornouse comum referir-se ao primeiro e ao segundo Império Português como o império asiático e o império atlântico (BOXER, 1981, p. 117-135). Tal terminologia visa a contemplar não apenas as características de cada um dos macroespaços citados, mas também a mudança que marcou a passagem de um para outro, enfatizando transformações nas relações entre as estratégias mercantis e as práticas governativas portuguesas. Do Índico ao Atlântico, a experiência acumulada passou por uma seleção capaz de adequá-la à nova realidade ${ }^{9}$. A Restauração em Portugal pode ser considerada o marco político dessa passagem, e não apenas por questões de conveniência cronológica, mas também por lembrar-nos da necessidade de relacionar as transformações no ultramar às mudanças sociais e políticas em Portugal ${ }^{10}$.

O império era antes de mais nada um sistema de redistribuição gerido pela Coroa portuguesa, servindo aos grupos que circulavam em torno da Corte ou que eram incorporados ao serviço régio ${ }^{11}$. Mudanças na correlação de forças em Portugal não podiam deixar de repercutir no ultramar, ao mesmo tempo em que a disputa viase constrangida pela dinâmica própria aos espaços coloniais, dos quais, mal ou bem, dependiam em grande medida, e com os quais se viam forçados a interagir. Apesar da tendência, bastante simplificadora, de se estudar as relações entre os diferentes espaços que o compunham em termos dicotômicos (v.g. Colônia-Metrópole), a história do Império Português possui uma dinâmica que só pode ser plenamente entendida ao levar-se em

9 Dom João IV deu-lhes início ao criar o Conselho Ultramarino em 1642 a Companhia Geral de Comércio do Brasil em 1649, a Junta de Conselho de Fazenda e a reinstalação do Tribunal da Relação, ambos na Bahia, em 1652 Sobre a Companhia Geral do Comércio, cf. Mello (1998a, p. 139-169); sobre o Conselho Ultramarino - "a maior reforma administrativa que afetou as colônias" -, a Junta de Conselho de Fazenda e a Relação da Bahia, ver Schwartz (1979, p. 192-193, 202).

10 Um excelente exemplo dessa relação é o debate das facções na Corte sobre as capitanias do Nordeste do Brasil em mão dos holandeses (MELO, 1998b, p. 119-124).

11 Para a definição de sistema de redistribuição, cf. Polanyi (1980, p. 63). conta a complexa rede de interesses que se sobrepunham, ora convergindo, ora transigindo, ora conflitantes, na disputa pelas oportunidades e benesses que a existência daquele proporcionava. Tais interesses não podem ser reduzidos a espaços fixos, como o modelo mais convencional postula, mas devem ser considerados como o que os contemporâneos identificavam claramente como facções, cujas conexões atravessavam o mar, e cuja composição era extremamente mutável, segundo a conjuntura política em meio à qual disputavam, ganhavam ou perdiam poder (CURTO, 1993, p. 145-147; BETHENCOURT, 1998, p. 303-314).

A Corte em Lisboa era uma importante referência, se não a principal, para as redes pessoais de clientela que organizavam interesses de natureza variada, incluindo os dos diferentes espaços ultra-marinos. Ambos os processos - a consolidação da Corte como espaço por excelência da ação política e a expansão ultramarina - podem ser pensados como constituindo dimensões de uma mesma configuração social, já que as relações de inter-dependência que fixavam os limites da primeira eram em parte informadas pelos circuitos de mobilidade social gerados pela conquista no alémmar. Como processo histórico singular, o surgimento de uma sociabilidade cortesã em Portugal incorporou características derivadas da nova realidade imperial, tanto na relação simbólica que a Coroa projetava impor ao conjunto de poderes que a cercavam quanto nas estratégias dos agentes individuais ou coletivos que disputavam o favor real. Para além da oposição entre a Corte e a aldeia, ou, em nova chave, entre a Corte e a capela - que reduz a análise aos limites de um Portugal continental -, há a continuidade entre a Corte e o ultramar (CURTO, 1993, p. 117-118). A distância física entre os dois espaços, assim, não deve elidir a possibilidade de pensá-los como coextensivos, ambos convergindo para a figura do Rei como chefe de uma casa alargada à dimensão de seus domínios ultramarinos.

Pode-se mesmo propor, por esse viés, uma abordagem que enfatize as continuidades que tal relação viabilizou em detrimento das rupturas que tradicionalmente se identificam. Se a disponibilidade de recursos franqueados à Coroa pela expansão ultramarina permitiu abandonar o conflito por jurisdições como estratégia de afirmação do poder régio, substituído por meios mais "doces", como a generosa distribuição de mercês e comendas, sua contrapartida foi a preservação de um ethos 
guerreiro que encontrava nos feitos da conquista a fonte ideal para a consolidação de estratégias reativas, agora deslocadas para o plano das representações. $\mathrm{O}$ alargamento das jurisdições no século XV, ao demandar o serviço de letrados capazes de defender a posição da Coroa e exercer suas prerrogativas por delegação, somou novos interesses ao embate entre o Rei e a constelação de poderes corporativos já existentes. Mas, ao mesmo tempo, a crescente importância desses letrados junto ao Rei disseminou formas de legitimação que terminaram repercutindo nas práticas daqueles poderes à medida que a Corte firmava-se como espaço privilegiado de disputa. O capital simbólico auferido com as novas estratégias de representação e legitimação facultou às casas senhoriais que passavam a interagir na Corte posição mais vantajosa frente ao mesmos letrados e, em última instância, ao próprio Rei (CURTO, 1998, p. 446-454).

A participação indiscutível de uma nobreza guerreira na conquista da Índia traduziu-se em processo histórico que singulariza a Corte portuguesa frente às demais. Não é o caso de lembrar aqui sua "precocidade", mas sim de identificar em meio à crescente interdependência entre o Rei, a nobreza e os letrados, o equilíbrio de poderes que lhe é específico, traduzido em práticas de representação mobilizadas pelos diferentes agentes envolvidos. Se, com o século XVI, a Corte tornase a referência e o espaço por excelência da ação política, permitindo ao Rei representar-se para além das disputas pelo poder, o princípio que pauta as relações entre este e os demais grupos, mormente a nobreza guerreira, vê-se apropriado de modo a garantir a esta última uma autonomia que a sociabilidade cortesã em princípio lhe negaria. Definindo-se pelo recurso às armas ao serviço do Rei, a nobreza portuguesa faz-se presente na Corte sem se identificar completamente com os valores cortesãos que esta dissemina, mais adequados às funções letradas, embora não possa dispensá-los completamente. Mas quando a eles recorre, tem em vista principalmente a afirmação de sua importância e do reconhecimento que lhe é devido na distribuição de cargos e benesses, traduzidos por sua vez em formas próprias de representação simbólica, disseminadas pelo conjunto do território para glória das respectivas casas. Ness ponto, o Império, a Corte e a capela alinham-se como etapas de um mesmo itinerário que o Rei põe, mas do qual ainda não dispõe.
De fato, mais do que um Rei acima das disputas, tem-se um Rei imerso nelas. Superada a fase guerreira do primeiro terço do século XVI, e consolidados os circuitos que drenam para os cofres régios as riquezas do oriente, é pela manipulação das representações que a nobreza mais tradicional terçará armas com aqueles que optam pela associação direta à imagem do poder real, servindo-a nos conselhos e no palácio, letrados laicos ou eclesiásticos ou filhos segundos (estes à espera de uma mercê que lhes permita fundar suas próprias casas). São recursos estratégicos que se traduzem em itinerários distintos: um que da Corte leva ao ultramar e daqui às posições de influência no Paço; outro que, por não abandonar o Paço, recorre mais acentuadamente às práticas cortesãs. Propôs-se uma diferenciação entre a nobreza guerreira associada às campanhas do Norte da África e uma nobreza surgida em meio à conquista asiática, mais associada ao trato e às rendas palatinas (LOUREIRO, 1989, p. 263-266). Mas não importando as diferenças de geração que porventura tenham se traduzido em estratégias distintas de acumulação material e simbólica, ambas se vêem à luz do serviço das armas, em contraposição aos letrados e cortesãos com foros de fidalguia que pouco contribuem para a "glória de Portugal" (SCHWARTZ, 1979 , p. 176-179) ${ }^{12}$. A própria natureza do debate, que irrompe quando das Cortes convocadas para jurar D. Sebastião, atesta que as opções à disposição limitam-se aos interesses alargados da nobreza.

É ainda a nobreza, portanto, que controla o leque de alternativas. A distinção entre uma nobreza "africana" e uma nobreza ultramarina parece traduzir não tanto a existência efetiva de dois grupos estanques, mas a representação dos interesses de facções que se associavam a membros da Casa real com o objetivo de garantir a maior latitude de movimento em meio às posições decisórias, ou seja, os assentos nos conselhos reais e outros cargos prestigiosos, como de confessor do Rei ou secretário particular. Note-se que nenhuma das representações coevas afins à nobreza nega-lhe $o$ papel guerreiro, mormente nas coisas da Índia. Não será por aí, com certeza, que passará a opo-

\footnotetext{
12 Ver também, sobre as estratégias de legitimação da categoriados letradose sua equiparaçãoànobreza, Hespanha (1993a, p. 27-42).
} 
sição entre ambas. E, assim, o que antes foi interpretado como entidades sociais pode ser lido como práticas discursivas adequadas a constelações singulares de interesses numa dada conjuntura, mutáveis ao sabor da correlação de forças em jogo, embora alicerçadas sob tópicos mutuamente compartilhados. O entusiasmo com que a campanha de D. Sebastião foi acolhida ilustra a plena vigência em Portugal do ideário militar da nobreza, e do peso que o serviço das armas ainda tinha como elemento justificador da mercê real (HERMANN, 1998, p. 92). Se as Cortes de 15621563 marcaram o início de uma virada na política ultramarina, privilegiando a África e o Brasil, essa virada não significou de maneira alguma uma redução da importância da Índia para certos segmentos da nobreza, pois por outras vias ainda era capaz de canalizar recursos assombrosos, tornando o cargo de vice-Rei cobiçado século XVII adentro $^{13}$.

\section{FACÇÕES ECOMERCIANTES: OCASO DO ESTADO DA ÍNDIA}

Abrir mão do estado da Índia, apesar das crescentes despesas que sua manutenção implicava, era uma proposta que pouco levava em conta o fato consumado de sua importância estratégica tanto para a Coroa quanto para diversas casas senhoriais e suas respectivas redes de clientelas. Como tópico de debate nas Cortes, pode ser interpretado como uma medida desesperada da parte de interesses alijados há demasiado tempo do Paço e que assim procuravam minar o poder dos que, à época, controlavam o acesso ao Rei e os meandros que levavam à nomeação de um posto na rede de fortalezas ou na Corte vicereal de Goa. Buscava provavelmente mobilizar apoio junto ao "povo" e aos descontentes na própria Corte, membros da família real inclusive, capazes de garantir maiores oportunidades na distribuição das rendas régias, mesmo as derivadas do ultramar. Os interesses das facções, proferidos na modalidade da "alta política" própria à razão de Estado, enraizavam-se nos objetivos imediatos imputados à "baixa política" da disputa entre bandos. A cada um caberia classificar-se e classificar os demais (CURTO, 1993, p. 145-147).

\footnotetext{
13 Com a exceção do período 1620-1650, quando as dificuldades provocadas pela guerra com os holandeses provavelmente reduziram as rendas do cargo e a sua atratividade (CUNHA \& MONTEIRO, 1995, p. 94 105).
}

As transformações por que passaram as relações entre a Coroa e a nobreza, em meio à afirmação da Corte como espaço de ação política, deram-se simultaneamente à ascensão de um poderoso grupo de comerciantes residentes em Portugal, formado a partir da Rota do Cabo e do monopólio régio. Começando com a arrematação de contratos para a equipagem das frotas, uma rede de comerciantes cristãos-novos acumulou enormes fortunas na razão direta da queda das rendas reais. Deveu-se tal situação tanto aos muitos compromissos da Coroa, incapaz de interferir na gestão dos assuntos orientais e empenhada em gastos diplomáticos ou com a manutenção da Corte, quanto às oportunidades abertas pelos espaços vazios nos porões das carracas que percorriam a Rota do Cabo. Sem condições de eliminar a concorrência dos comerciantes mulçumanos e venezianos (por meio do fechamento da rota do Mar Vermelho), a Coroa via os lucros da comercialização da pimenta na Europa caírem, enquanto as despesas com a manutenção do aparato imperial na Ásia consumiam montantes cada vez maiores. Procurando garantir preços mais compensadores, optou pela redução dos envios da especiaria, o que permitiu aos comerciantes que participavam dos negócios asiáticos aumentarem o embarque de outros produtos não-monopolizados mas com bom preço. Como comissários de poderosos senhores agraciados pelo Rei com isenções alfandegárias e quotas na importação da pimenta, recebendo comissões pela compra e pelo envio da mesma, haviam se estabelecido nos portos do Índico sob controle português ao longo do meio século anterior, e estavam em condições de tirar o melhor proveito dessa oportunidade. O sucesso de suas estratégias mercantis ficou evidente quando, em meio à discussão sobre o destino a ser dado ao Estado da Índia, terminaram por arrematar o contrato da compra da pimenta, em 1570 (BOYAJIAN, 1993, p. 1-28).

A arrematação de tal contrato vinculou definitivamente aqueles comerciantes à política da Coroa portuguesa e, conseqüentemente, à disputa entre facções na Corte. Como representantes e sócios da nobreza nos negócios da Índia, já possuíam acesso aos corredores do Paço. Como banqueiros do Rei, viam-se alçados ao palco principal, convertendo a fortuna acumulada no Oriente em prestígio e mercês. A incorporação do Reino de Portugal à Coroa dos Habsburgo espanhóis abriu-lhes novos mercados, mormente o da prata 
espanhola, via arrematação do contrato de escravos africanos. Presentes na Ásia, na África e na América, o pequeno grupo de famílias cristãs-novas que geria os circuitos interligados da prata, dos escravos africanos e das fazendas asiáticas tornouse a primeira rede mundial de negociantes da história (idem, p. 29-52). A fortuna e o poder das famílias de comerciantes de grosso-trato portuguesas serve como indicador da vitalidade dos negócios da Índia, apesar da propalada decadência que se teria abatido sobre a mesma a partir de meados do século XVI. Tal visão decorre de uma confusão bastante freqüente entre os negócios do Rei e os de seus vassalos, e a distinção entre ambos permite entender o papel que o Estado da Índia assumia no jogo político português durante a segunda metade do século XVI e primeiro terço do XVII - papel esse posteriormente desempenhado pelas possessões atlânticas.

Para tanto, deve-se levar em conta a forma de atuação dos funcionários régios portugueses no Índico, as relações destes com os comerciantes, e de ambos com a Corte em Lisboa. A partir daí, será possível pensar a continuidade ou não dessas relações em meio às transformações que deslocaram o eixo do império do Índico para o Atlântico. Antes de mais nada, deve-se ressaltar o caráter militar de sua organização, como já observado. Tratava-se da transposição para o Índico de "um rosário de praças fortes característico da expansão portuguesa no Norte da África, permitindo a perpetuação do predomínio político da nobreza militar", ao qual se subordinava um outro modelo, o da organização comercial, desenvolvido na etapa africana ocidental, ou da Guiné, baseado na disseminação de feitorias (THOMAZ, 1994, p. 213). Nas fortalezas, sob cuja guarda desenvolveu-se o comércio regulado pela Coroa, postavam-se capitães que acumulavam tanto poder civil quanto militar, mas que terminaram por ceder as funções jurídicas a magistrados de carreira e as fiscais a vedores ou feitores da fazenda (estas últimas, entretanto, variando segundo os sistemas tributários nativos em vigor). Com exceção dos magistrados, tais cargos podiam ser concedidos como recompensa por serviços prestados ou arrematados por determinado número de anos. Com a política adotada após Afonso de Albuquerque, o corso contra os navios não-licenciados perdeu espaço para a atividade tributária e comercial, mas que ainda se fazia sob um clima de beligerância crônica. Mas a iniciativa militar limitava-se, na costa ocidental, aos oficiais nomeados pela Coroa, e não mais às tropas arregimentadas pela pequena nobreza em busca de saques. Cabia aos mesmos controlar o comércio, zelando pelo monopólio régio da pimenta e preservando os direitos que a Coroa vendia ou concedia graciosamente, única forma legal de participar dos mercados asiáticos.

Contudo, com a queda dos rendimentos reais e o aumento das despesas, tornavam-se mais escassos os montantes em moeda destinados ao pagamento dos salários desses funcionários, que recebiam igualmente licenças para realizar certo volume de negócios. Como lhes faltasse a experiência ou o capital necessários para usufruí-las, associavam-se a comerciantes capazes de convertêlas em dinheiro. Tais sociedades resultavam, com o tempo, em práticas que contornavam o monopólio régio, mas que eram toleradas, posto que esses mesmos comerciantes inseriam-se em redes capazes de, ao fim, acumularem impressionantes fortunas, e às quais o vice-Rei e o erário régio recorriam para fazer frente às despesas de manutenção das ditas fortalezas e, principalmente, da preparação anual da Carreira da Índia (idem, p 197202). A partir da segunda metade do século XVI, a presença da Coroa portuguesa na Índia viu-se imbricada à existência de uma sólida comunidade mercantil que procurara décadas antes conter.

A consolidação do Estado da Índia supôs, então, a multiplicação de cargos militares, fiscais e jurídicos passíveis de serem convertidos em poder através da formação de redes de clientela. Essas redes, por sua vez, bloqueavam insistentemente qualquer tentativa de reforma mais radical capaz de reforçar o controle da Coroa sobre as rendas geradas pelos circuitos marítimos asiáticos. Tanto os funcionários mais graduados em Goa, quanto seus patronos na Corte, preservariam com afinco a base de seu poder, seja simbólico, seja material, e que se traduzia na possibilidade, por meio de clientes estrategicamente situados, de participar das oportunidades de comércio legal e ilegal. Os comerciantes, por outro lado, eram elementos vitais dessas redes de clientela ao aportarem recursos financeiros e experiência em troca da anuência e do apoio daquelas autoridades às suas transações. Constituíam eles mesmos outras redes que se ramificavam a oriente e alcançavam a América, e em seu cume reuniam-se fortunas que um Rei não seria capaz de ignorar. Incrementavam assim, como sócios, aliados ou clientes, a ação das facções que lhes davam guarida e que 
mobilizavam na defesa de seus próprios interesses.

Mas tais redes nem sempre encontravam na Corte um pólo organizador. Por vezes se reproduziam à revelia dos grupos que tinham acesso direto à figura real, ou aos seus representantes de maior prestígio, concorrendo com estes pela apropriação das rendas ultramarinas. Um outro indicador do sucesso na apropriação dos cargos e das rendas de ultramar foi a diáspora de comerciantes e soldados em busca de melhores oportunidades para além da área de jurisdição efetiva do Estado da Índia. Aqueles que não conseguiam uma nomeação para um dos cargos de capitão das fortalezas e das carreiras oficiais que interligavam Goa aos demais portos do Estado da Índia, ou vedor nas feitorias, encontravam poucas oportunidades de participar do comércio regular. Seguiam então para as áreas não abrangidas pelo sistema de concessão de "cartazes" (licenças), constituindo comunidades mercantis que escapavam à jurisdição dos funcionários reais. Os homens que se dispunham à aventura de um comércio lucrativo abriam mão, por outro lado, da proteção que o Estado português poderia eventualmente lhes garantir. $\mathrm{Na}$ verdade, tornavam-se concorrentes daqueles funcionários régios responsáveis pela preservação do sistema de licenças e, conseqüentemente, possíveis presas dos capitães dos navios que eventualmente patrulhavam aquelas rotas. Embora a composição do grupo de "aventureiros" ou "renegados" fosse bastante diversificada, muitos dentre eles procuravam pôr em prática estratégias que, no longo prazo, permitissem-lhes a reintegração ao "mundo português" em melhores condições financeiras, o que muitos individualmente conseguiram, ao estabelecerem relações com as comunidades locais e, por meio destas, com os circuitos mercantis que atravessavam a vasta extensão compreendida entre o Cabo Comorim e Macau (SUBRAHMANYAM, 1994, p. 35-63, 111-140).

Por mais bem-sucedidas que essas redes fossem, todavia, eram marcadas pela marginalidade própria aos que não se inseriam na malha de cargos e poderes que regulavam, em alguma medida, a res publica, faltando-lhes a legitimidade que emanava do Rei por delegação. Vemos, assim, que muitos aventureiros dispunham-se a intermediar as relações entre o Estado da Índia e os Reinos espalhados pela costa da Birmânia e do arquipélago indonésio, como embaixadores ou chefes de expedições militares, apresentando-se perante o vice-
Rei em Goa como servidores do Rei e em condições de receberem o reconhecimento e a posição correspondente. Em outros termos, a concessão do posto de capitão de alguma fortaleza ou feitor, com a jurisdição e os privilégios correspondentes. Esse movimento criava um círculo vicioso, chegando a ditar o ritmo de expansão do Estado da Índia no Golfo de Bengala, na esteira dos empreendimentos daqueles "lançados", a ponto de um especialista no assunto denominá-lo como "a calda que abana o cão" (SUBRAHMANYAM, 1994). Como resultado, induzia os refratários a se associarem aos que, por meio do real serviço, detinham os mecanismos legítimos de controle que hierarquizavam as oportunidades de negócios, ascensão social e prestígio (idem, p. 141-173).

\section{O REI, AS REDES DE CLIENTELA E A PO- LÍTICA EM PORTUGAL ANCIEN RÉGIME}

No limite, a intricada rede de cargos e jurisdições que viabilizavam a presença da autoridade régia, identificando o bom governo à aplicação da justiça, constituía-se numa extensa rede de clientela cujo patrono era o próprio Rei, pessoalmente, ou na figura de seus conselhos e tribunais. A relação entre a formação de rede de clientelas e justiça realizava a junção entre dois pólos coextensivos do universo social português entre os séculos XV e XVIII, e é a partir dessa relação que se pode caracterizar a lógica comum que informava as estratégias dos diferentes agentes na disputa por ganhos materiais ou simbólicos.

O primeiro pólo refere-se à dimensão informal das relações de poder que perpassava a dimensão jurídica - e, portanto, formal - das identidades corporativas, dando maior dinamismo às suas configurações. Esse dinamismo advinha da grande flexibilidade que a economia de favores atribuía ao processo de constituição, reprodução e expansão das redes de clientela. Franqueava a uma sociedade vincada por distinções hierarquizantes certa mobilidade social que, ao invés de pôr em risco aquela hierarquia, contribuía para seu reforço. Derivava tal resultado da natureza incomensurável que a doação de um benefício instaurava entre benfeitor e beneficiado. Seu caráter incerto "instituía um campo indefinido de possibilidades de retribuição", tanto no que diz respeito a sua natureza quanto à duração do débito assim gerado. Isso possibilitava ao benfeitor, que podia dispor de recursos materiais e simbólicos relativamente escassos, "manter uma vantagem de poder sobre 
quem estava em falta", pois a contrapartida da parte do beneficiado era a disponibilidade de prestar serviços definíveis apenas futuramente e a critério do primeiro. Ao dar, o benfeitor ou patrono confirmava ou reforçava sua posição social, e tais atos deveriam ser marcados pela liberalidade e magnificência, garantindo o impacto político desejado. Quanto maior fosse o número de favores prestados, e mais variados em natureza, mais ampla seria a conversão dos recursos materiais e simbólicos em poder passível de ser mobilizado. A liberalidade e a magnificência publicizavam tal poder, adequando-o à posição social pretendida, mesmo fim a que se destinavam os gastos suntuários. $\mathrm{O}$ patrono, por sua vez, podia ser ele mesmo beneficiado e, simultaneamente, um intermediário, nessa posição, sobressaía sua capacidade de pôr em contato, pelos conhecimentos que possuía (o que terminava por ser também uma espécie de capital simbólico) patronos mais poderosos e demandantes que ele mesmo não seria capaz de satisfazer. Auferia, desse modo, os "dividendos políticos" da nova relação de clientela a que dava origem, acentuando sua forma radicular. De fato, todos os patronos terminavam, ao fim, intermediários, pois nenhum podia se equiparar ao Rei na capacidade de dispensar favores, em geral os mais desejados (XAVIER \& HESPANHA, 1993, p. 381-389).

Como provedor privilegiado de benefícios, fossem mercês, fossem graças, o Rei selecionava e circunscrevia. A proximidade da pessoa real distinguia, por abrir oportunidades de ganhos materiais e simbólicos negadas a qualquer outro intermediário. Sua ação circunscrevia na medida em que gerava organismos nos quais se institucionalizava a capacidade de prover aqueles bens, criando fontes derivadas e paralelas de benefícios. Ao lado da nobreza guerreira, que considerava como atribuição natural tanto o serviço das armas quanto a prestação de conselho, mas que pela sua própria força convinha não favorecer em demasia, o Rei recrutou agentes que não contavam com o prestígio do título e do sangue. Os letrados eram clientes ideais, pois a grande desigualdade entre patrono-príncipe e cliente-vassalo multiplicava a gratidão e os serviços correlatos que estes dispunham-se a prestar, sem mais garantias que a liberalidade real, neste caso passível de limitar-se aos benefícios mais modestos. A criação dos tribunais palatinos ao longo dos séculos XV e XVI serviu de modelo para os demais órgãos responsáveis pela condução da política régia. Tratava-se de modelo paradigmático, pois dispensar justiça era a principal atribuição da Coroa. A partir destes tribunais, expandiu-se a rede de magistrados selecionados em função de competências específicas e avaliados pela estrita observância dos objetivos régios. À medida que tais magistrados procuravam legitimar-se frente à nobreza de espada, que ao fim e ao cabo, ocupava o ápice da hierarquia social e constituía o objetivo último das estratégias de ascensão social, as prerrogativas exercidas em nome do Rei passaram a ser apropriadas como atribuições corporativas que ao próprio Rei cabia respeitar. Identificados com a Coroa, seus membros passaram, eles mesmos, a distribuir clientes pelos cargos sob sua alçada, compondo redes institucionalizadas ou, pelo menos, corporativizadas.

A concentração de poderes no topo da pirâmide não garantia, contudo, que tais redes fossem estanques. Por um lado, a identidade corporativa de tais instâncias era constantemente atravessada por outras filiações, permitindo associações e a manipulação de múltiplas identidades, como as de parentesco ou de naturalidade. Crescia o leque de estratégias disponíveis e, proporcionalmente, as zonas de atrito e os agentes envolvidos. Por outro lado, o alto grau de autonomia e os precários mecanismos de controle das atribuições, derivados da incipiente burocratização dos ofícios régios e da polarização entre a base e o topo, estimulavam a formação de associações entre as posições situadas na base das diferentes hierarquias, tornando muito mais complexos os padrões de cooperação e conflito entre agentes. Era grande a distância entre os membros mais graduados de uma área específica do governo e aqueles dos escalões inferiores, e enquanto os primeiros reduziam-se à seleta elite que não ultrapassava a casa das dezenas, quando muito, uma miríade de pequenos ofícios pulverizava as atribuições dos postos mais modestos, sem instâncias intermediárias que mediassem as relações entre eles (SCHWARTZ, 1979, p. 56-58; HESPANHA, 1994, p. 516-522). Também aqui as fidelidades podiam igualmente extrapolar as respectivas jurisdições, embaralhando-as. Muitos dos conflitos em torno de atribuições e privilégios originavam-se das alianças que colocavam em lados contrários funcionários de uma mesma área específica, como justiça e fazenda, por exemplo, ou governo civil e eclesiástico. Essas alianças terminavam por quebrar as hierarquias oficialmente estabelecidas nos regimentos, por meio dos quais se 
fixavam deveres e jurisdições, mas que encontravam na prática tradução diversa.

Tais características apenas reforçavam a premência de inserção nas ditas redes, consolidando-as e expandindo-as, pois se assim não fosse viam-se reduzidas em muito as possibilidades de garantir os privilégios e oportunidades considerados adequados às posições ocupadas. As alternativas abertas aos agentes configuravam uma dinâmica instável e tensa, dados os diferentes vínculos passíveis de serem mobilizados a cada ocasião. Desenhava-se um quadro de grande fluidez, definido apenas pela lógica patrimonial-corporativa comum que pautava as relações entre os envolvidos.

A disputa inerente à existência das redes de clientela dava origem à incessante seqüência de litígios que constituía o espaço político próprio às sociedades do Antigo Regime. Política, aqui, tornava-se equivalente à defesa de prerrogativas $\mathrm{e}$ privilégios que garantiam a identidade dos diferentes corpos que compunham aquela sociedade, equivalendo à noção coeva de "justiça", principal característica do "bom governo" da res publica. Aquela não se pautava pela igualdade entre os corpos, mas pela hierarquia de lugares a que pertenciam no interior do organismo político (CARDIM, 1998, p. 19-21; HESPANHA, 1994, p. 297-307). Não se questionava o próprio ordenamento, mas os limites que singularizavam cada corporação em relação às demais, demarcando suas competências e prerrogativas. O conflito, nesse caso, assumia a forma de litígio passível de ser regulado pelo Direito. As instâncias de disputa eram ao mesmo tempo as que detinham, por delegação, o poder de interpretar e fixar o sentido da lei, da qual o Rei era o principal depositário e defensor, mas não o único (HESPANHA, 1994, p. 484-487).

É conveniente chamar atenção para o fato de que o Rei possuía a atribuição de legislador na medida em que era identificado com o próprio Reino, encarnando a res publica que tem por dever preservar (KANTOROWICZ, 1998). Sua tarefa era, por meio da atividade legislativa, estabelecer a posição adequada e esclarecer o conjunto natural de direitos que pertenciam a cada um dos litigantes, entendidos como partes de um corpo maior que não se pretendia modificar. O Rei, nesse sentido, devia remeter-se sempre ao conjunto já instituído de leis que procurava apenas aperfeiçoar.
Do mesmo modo que a política era uma dimensão da justiça, a atividade legislativa também o era. $\mathrm{O}$ corpo místico da res publica, com o qual se identificava o Rei, era, simultaneamente, a origem do poder soberano que estabelecia o que cabia a cada uma das partes - o que só podia ser feito de maneira pontual, à medida que se apresentavam os casos. A enorme pletora de alvarás, cartas régias, decretos e leis que se multiplicam e se contradizem deve ser lida a partir dos objetivos imediatos que procuravam alcançar, quais sejam, definir e garantir os direitos singulares e preservar a res publica, entendida como bem comum.

Sendo a atividade legislativa corolário da justiça, e sendo esta que assentava os conflitos, fazse evidente a importância de vincular-se aos agentes que ocupavam as posições legítimas de decisão. Os conflitos eram decididos a partir dos critérios mais gerais de bem comum, quando não das prerrogativas reais, um sucedâneo daquele princípio mais geral. Procuravam contemplar, entretanto, a variedade de direitos corporativos que tornava possível sua aplicação em meio à singularidade de personas e casos, havendo grande margem de indecisão sobre quais dentre os direitos atendiam melhor àquele objetivo mais geral. Se por um lado permitiu aos litigantes apresentarem suas demandas como justas, por outro forçava-os a recorrer às instâncias decisórias como árbitros das contendas. Além disso, a casuística que regia tais decisões permitia a constante renovação de litígios, e uma decisão desfavorável num dado momento não desestimulava o contínuo recurso às alianças pessoais que propiciassem, no futuro, uma vitória ${ }^{14}$. As redes de aliança e clientela resultavam em elemento inerente às relações do Antigo Regime, traduzindo na prática a lógica que regia o raciocínio jurídico.

A decisão, desse modo, não anulava um direito em detrimento de outro, apenas estabelecia qual prerrogativa prevalecia em cada caso, permitindo que a contenda fosse retomada mais adiante, já que se podia alegar que sua natureza era distinta.

\footnotetext{
14 Sobre aimportância da casuística que informavaa tomava de decisões e o procedimentojurídico propriamente dito no Portugal Ancien Régime, ver Hespanha (1984, p. 85-86); para um estudo das relações entre normas jurídicas e práticas sociais, esuaimportância paraa definição de valores legítimos que conformam a identidade dos agentes envolvidos em litígios, cf. Cerruti (1995, p. 137-149).
} 
Constata-se que os privilégios dos corpos, invocados em cada caso, mesclavam-se à pessoa que os portava. Esta, por sua vez, era capaz de nomear várias identidades corporativas ${ }^{15}$ segundo a ocasião, multiplicando as possibilidades de defender a inadequação das decisões anteriores ao seu caso particular. Como as relações entre pessoas e grupos não era fixada a priori, o litígio era considerado a expressão política comum dos interesses imediatos de cada pessoa ou corporação particular. Se cada uma das partes possuía direitos e prerrogativas incontestáveis, a equivalência entre estes era resultado de decisões que dependiam da correlação de forças a cada momento dado. A probabilidade de cada um impor aos demais este conjunto de privilégios dependeu, conseqüentemente, da sua capacidade de tecer o mais amplo leque de alianças, somando as opiniões e influências a seu favor. A estrutura sinodal das instâncias decisórias de último recurso, no ápice das diferentes hierarquias burocráticas, refletia a pluralidade de posições e a diversidade de resultados. Cabia às partes atrair para o seu lado o apoio do maior número de personas capazes de influenciar a decisão, o que podia depender de um conjunto extremamente intricado de fatores, apenas definíveis e passíveis de serem avaliados no contexto da própria disputa.

\section{OFÍCIOS RÉGIOS, COMÉRCIO E PODER: O ATLÂNTICO PORTUGUÊS NOS SÉCU- LOS XVII E XVIII}

A prática de concessão de pequenos cargos como recompensa por serviços prestados, por sua vez, tornava ainda mais instáveis as configurações que surgiam a partir da disputa pela sua obtenção. Os cargos de maior prestígio, remuneração e poder eram destinados, em princípio, aos letrados e aos membros da fidalguia, recrutados em meio a fileiras relativamente seletas e pouco numerosas. $\mathrm{O}$ grau de contato social entre eles, em sua grande maioria formados em uma mesma instituição - a Universidade de Coimbra - ou já pertencentes a alguma rede com conexões no Paço, permitia a socialização de certos códigos de conduta e de valores que conferiam maior homogeneidade e durabilidade aos laços pessoais que conduziam às posições almejadas (SCHWARTZ, 1979, p. 233234; GOUVEIA, 1993, p. 415-430; ELIAS, 1995,

\footnotetext{
15 Paraumestudo da formação das identidades corporativas emsociedades do Antigo Regime, verCemuti (1998, p. 190 201).
}

p. 53-90). Os cargos mais modestos, por sua vez, incorporavam ao jogo político um número muito maior de participantes. A origem social destes, pode-se supor, era bastante diversificada, e sua procedência nem sempre coincidia com o local de exercício da posição conferida ${ }^{16}$. Por outro lado, tais cargos eram concedidos por pequenos prazos, geralmente em torno de três anos, incorporando uma gama variada de tipos sociais às negociações necessárias à manutenção dos interesses em jogo, os quais poderiam colidir pela própria diversidade de personagens envolvidos. Enquanto os que ocupavam posições de preeminência podiam ter em vista mais do que apenas ganhos materiais imediatos - como sabemos ser comum pelo numeroso rol de queixas e disputas quanto a questões de etiqueta e precedência -, os que almejavam postos de menor prestígio encaravam-nos como apenas mais um recurso dentre outros à sua disposição para amealhar algum pecúlio. Não se tratava, como no primeiro caso, de uma escala numa possível trajetória de ascensão dentro da hierarquia laica ou eclesiástica, mas de um investimento de curto prazo, rentável por si mesmo. Obviamente, a experiência e as relações que se podiam acumular durante seu exercício constituíam um capital simbólico de certa importância. Mas, provavelmente, a posse de um pequeno cargo e a prática do ofício correspondente viam-se menos vinculadas às considerações corporativas, permitindo maior liberdade de movimento ao seu ocupante, vetada aos demais em função das considerações de promoção. A maior mobilidade, por sua vez, resultava em práticas especulativas mais acentuadas e maior rotatividade entre seus detentores. Os pequenos cargos franqueavam a um conjunto mais vasto de agentes, relativamente modestos, a participação ativa na apropriação das rendas sob sua alçada e o correspondente poder de barganha junto aos demais interessados.

\footnotetext{
16 Cargos camarários eram majoritariamente detidos por pessoas com vínculos locais bem estabelecidos. Mas havia umgrande número de outros pequenoscargosque escapavam àjurisdição dos concelhos municipais, como os de fazendae justiça, ou diretamente sob a alçada do govemador. Estes podiam ser concedidos em mercê régia a pessoas recémchegadas ou de outras localidades. Cargos concedidos como dotes, por exemplo, habilitavamos que se dispunhamacasar comórfãs beneficiadas a ocupá-los sema necessidade de outras relações junto aos residentes da localidade aonde viesse a ser exercido (cf. COATES, 1998, p. 243-247).
} 
Não se pretende dizer com isso que os pequenos cargos não pudessem ser estratégicos. Dependendo da função a ser outorgada, podiam compor um elo importante das redes organizadas para se apropriarem de rendas régias. De fato, a importância atribuída a esses pequenos cargos só pode ser entendida se os considerarmos sobre esse prisma. Tanto aqueles que os postulavam quanto a Coroa reconheciam que seu valor advinha da possibilidade de seu ocupante empregá-lo como um meio para o exercício de práticas que, na letra da lei, seriam consideradas ilícitas. Um bom exemplo é a forma como ambos encaravam a questão do contrabando. Há uma excessiva preocupação, por parte de uma historiografia mais tradicional, em enfatizar o contrabando como crime, em decorrência do formalismo com que costuma abordar as relações entre as diferentes instâncias de governo. Ele seria visto como uma consequiência lógica do sistema de exclusivo que pautaria as relações entre a metrópole e a colônia. À medida que o sistema "amadurece", o contrabando tornar-se-ia um dos elementos que levariam à sua crise terminal. Nesse sentido, ele é constante objeto de preocupação da parte dos organismos metropolitanos, que procurariam combatê-lo insistentemente, apesar do alegado fracasso das medidas punitivas, baixadas uma atrás da outra (NOVAIS, 1986, p. 90-91). Uma justificativa para tanto seriam os baixos salários recebidos pelos funcionários, o que estimularia por parte da Coroa uma atitude de tolerância para com o contrabando, liberada da necessidade de aumentar os proventos dos funcionários régios ${ }^{17}$.

Tal perspectiva ignora completamente a complexa rede de relações sociais que se organizavam em torno de tal prática, integrando funcionários régios e grupos locais e reduzindo o grau de con-

\footnotetext{
17 Tentando reduzir a pressão fiscal sobre as câmaras municipais, responsáveis em parte pelo pagamento do salário do govemador, e poupar-se de maiores desembolsos, a Coroa permitiu em 1711 a prática de comércio aos govemadores. Mas pouco mais de uma década depois voltou atrás, em 1723, preferindo conceder um aumento de salário em compensação pela redução dos rendimentos daqueles funcionários. Contudo, não se deve deduzir daí, como argumentado, que a Coroa e os funcionários régios viamesta questão apenas do ponto de vistafinanceiro. Como veremos emseguida, considerações de outra ordem informavamas relações entre ambos e destes com os demais agentes envolvidos no comércio legal ou não (cf. PINING, 1997, p. 274276).
}

flito entre si. Assim como os funcionários da Relação da Bahia estabeleciam relações de amizade ou parentesco com os grupos locais, o que era expressamente proibido pelo seu regimento, outros funcionários toleravam ou mesmo participavam do contrabando, posto que tais práticas demandavam a constituição de vínculos pessoais com membros da elite local, que as encarava como algo costumeiro, à revelia das proibições em contrário (SCHWARTZ, 1979, p. 251-285). O combate sistemático ao contrabando podia criar atritos desnecessários entre grupos de interesse com poder e influência, passíveis de serem mobilizadas contra o funcionário em questão. Fazendo parte das práticas de acumulação locais, a distribuição das oportunidades dava-se de modo a impedir que um único grupo alijasse os demais. Quando isso acontecia, o conflito era praticamente inevitável. Provavelmente tratava-se de uma das poucas ocasiões em que a lei era efetivamente demandada, mas quando tal acontecia, era sempre em favor de um grupo contra o outro, e não pelo reconhecimento tácito da lei em $\mathrm{si}^{18}$.

No primeiro caso, os eventuais prejuízos à autoridade e ao erário régios eram compensados pela manutenção da paz necessária à continuidade dos negócios. Não se tratava da impossibilidade de intervenção por parte da Coroa, mas dos riscos que tal intervenção trazia para a preservação do status quo. Em certa medida, não só no que diz respeito ao contrabando, mas a todo um conjunto de práticas ilícitas, a complacência da Coroa significava o reconhecimento da importância da colaboração das elites locais, que se traduzia em contribuições extraordinárias, na cessão de bens e escravos, ou no esforço militar de que aquela não podia dispensar (como ficou comprovado durante a Guerra de Restauração), mas que se faria necessário demandar em ocasiões futuras (BOXER, 1973, p. 267-269; MELLO, 1998a, p. 170-192).

No segundo caso, as disputas que levavam às denúncias de abuso de poder e enriquecimento ilícito permitiam à Coroa implementar reformas pontuais, reduzindo a esfera de intervenção dos grupos locais em favor de funcionários diretamente

\footnotetext{
18 Para estudos de caso sobre o Império Espanhol que trabalharam com conflitos entre grupos em disputa pelas oportunidades de comércio ilícito, ver Mbutoukias (1988 p. 791-801) e Andrien (1982 p. 58-71); para o caso do Rio de Janeiro setecentista, cf. Pjining (1997, p. 183-223).
} 
ligados a Lisboa. Embora não fosse comum a venda de cargos importantes, alguns haviam sido concedidos como mercê régia, ou cedidos em usufruto mediante a doação de parte da renda a ser auferida durante o seu exercício, a pessoas com fortes vínculos pessoais ou interesses econômicos bem enraizados localmente (o que constituía, na prática, o arrendamento do cargo). Entre aqueles cargos, os de maior influência eram os vinculados à alfândega e ao tesouro (PJINING, 1997, p. 263-320). Tentando recuperar o controle sobre tais ofícios, a Coroa exercia seu poder arbitral nos momentos de conflito de jurisdição, conciliando objetivos políticos mais modernos com concepções juridicistas mais tradicionais ${ }^{19}$. Nem sempre com os resultados esperados, tais intervenções começaram a se tornar mais freqüentes a partir da segunda metade do século XVII, com a reinstauração do Tribunal da Relação em Salvador e a criação do cargo de Juiz de Fora, expandindo-se para a região Centro-Sul com mais um Tribunal da Relação no Rio de Janeiro.

O aspecto pontual da legislação que visava regular as relações entre os diferentes ofícios régios e estabelecer suas respectivas áreas de jurisdição assume, nesta perspectiva, um outro significado. A sucessão de alvarás e outros instrumentos jurídicos, que poderiam indicar tanto a aleatoriedade das diretrizes régias quanto os escassos resultados obtidos na sua implementação, refletiam a relação de forças entre Coroa, funcionários régios e interesses locais. $\mathrm{O}$ afastamento de funcionários, a transferência de jurisdições e a criação de novos cargos, vistos na longa duração, indicariam os momentos mais favoráveis, aos olhos da Coroa, para a defesa de seus interesses. Ao punir segundo a lei um determinado funcionário, a Coroa legitimava seu poder e autoridade, preservando sua imagem de instância que pairava acima dos interesses dos diferentes grupos, mesmo aqueles ao seu serviço, reduzindo ao máximo a repercussão negativa que as reformas poderiam

\footnotetext{
19 Sobre a forma como a Coroa empregava os conflitos de jurisdição para substituir agentes locais por funcionários régios por ela diretamente nomeados, cf. Pjining (1997, p. 225262); para a diferença entre concepções "políticas" e concepções “juridicistas”, ver Monteiro (1998, p. 510-511). Tendo em vista o já exposto, o termo "Coroa" empregado daqui por diante supõe tanto a naturezasinodal das instâncias decisórias quanto os conflitos entre faç̧õese redes de clientela emseu interior.
}

ter aos olhos do conjunto da comunidade assim $\operatorname{afetada}^{20}$.

O estabelecimento da esfera de ação de um funcionário régio constituía-se em importante variável nas estratégias individuais de acumulação. $\mathrm{O}$ mercado em sociedades do Antigo Regime caracterizava-se por ser extremamente segmentado. Ela derivava da hierarquização que distribuía desigualmente oportunidades e capacidades entre os diferentes agentes. Monopólios, privilégios, concessões e isenções fixavam o lugar de cada um no interior do mercado. A capacidade de deslocar-se verticalmente, atingindo posições mais vantajosas, ou seja, de maior poder regulador, derivava em tal sociedade diretamente da intervenção régia, já que era a partir de sua decisão que se estipulavam o limite de ação de cada uma das entidades sociais. As atividades consideradas ilícitas não passavam do outro lado da moeda. Contrabando e sonegação faziam parte integral dessa realidade, na medida em que eram práticas que procuravam contornar as desvantagens de acesso a bens e recursos cuja distribuição correspondia ao estatuto jurídico de cada um dos concorrentes. Todos, de certa maneira, dispunham-se ao seu exercício em detrimento daqueles que, por controlarem legalmente $o$ acesso aos bens, auferiam vantagens junto aos consumidores ou distribuidores. A hierarquização estava na origem do contrabando e de outras práticas ilícitas, contando com a conivência ou tolerância das autoridades régias que tinham por obrigação coibi-lo. Contrabando ou fraude, portanto, não devem ser contrapostos a monopólios - que seriam peças de sistemas mercantis descontextualizados - mas a privilégios e jurisdições cuja realidade dependia de escolhas estratégicas referidas a contextos bem definidos.

$\mathrm{O}$ efetivo exercício pelos funcionários régios das respectivas jurisdições guiava-se pela aplicação a cada caso particular de normas mais gerais, levando-se em consideração tanto os interesses imediatamente envolvidos e afetados como o conjunto mais vasto de relações que estes mobilizavam. Tratava-se de associar a aplicação da lei à lógica personalizada que sempre supunha a desigualdade de posições entre as partes e a defesa das suas prerrogativas como fontes de direito por delegação.

\footnotetext{
20 Para as limitações que cerceavamo poder que a Coroa exercia sobre a transferência dos cargos arrendados ou doados, ver Hespanha (1994, p. 509-511).
} 
Ou seja, na defesa do poder de decidir quem, quando e em quais condições teria acesso ao mercado, o que não passava de um desdobramento do princípio mais geral pelo qual se pautava o direito comum: o da casuística através da qual se circunscreviam os limites que separavam os diferentes corpos e identidades sociais. O funcionário régio era responsável pela interpretação da lei, realizando a ponte entre o princípio mais geral e o caso particular ao qual se aplicava. Era essa a principal característica de seu poder, que só tinha vigência se aplicado criteriosamente. Com isso, fechava-se o círculo de ferro no qual se via presa a Coroa na sua relação com os oficiais régios. Ao afastar determinados funcionários em favor de outros, que lhe eram mais diretamente ligados, a Coroa conseguia ganhar maior capacidade de regular aquele mercado e as respectivas relações que o constituíam. Mas a lógica que norteava as relações entre os funcionários régios, e destes com os demais poderes e interesses existentes num dado contexto, estimulava os recém-nomeados a retomarem as práticas de seus predecessores, sob nova configuração, com o intuito de afirmar seu poder e consolidar sua jurisdição.

Era o ato discricionário que traduzia na prática a legitimidade suposta na lei. Como aparente paradoxo, agora facilmente inteligível, um oficial régio que aplicasse a lei sem levar em consideração tal princípio rapidamente se veria isolado, em meio às demais redes de influência e clientela já constituídas, desqualificando-se aos olhos da comunidade por não ter discernimento suficiente para tratar cada caso segundo as prerrogativas oficiais ou informais, estas últimas consensualmente reconhecidas, dos envolvidos. Outro que não procurasse pôr em prática aquele poder, selecionando com discernimento os que pretendia favorecer, veria rapidamente sua capacidade de intervenção apropriada pelos demais funcionários em posição de fazê-lo, reduzindo-se tudo a um jogo de soma zero no qual quem não ganha perde. Resultava, assim, que após certo tempo, as práticas informais ou ilícitas eram retomadas, forçando a Coroa a nova intervenção, com vistas a realinhar o conjunto de forças em disputa e, mais uma vez, afirmar sua autoridade, em uma espiral derivada do sistema de pesos e contra-pesos que informava as relações não apenas entre os funcionários régios, como se costuma lembrar, mas entre todos os agentes sociais.

Decorrência interessante dessa forma específi- ca de exercício do poder foi o modo como a punição era aplicada aos que sofriam as consequiências das reformas administrativas encetadas pela Coroa. Uma leitura demasiado colada à letra da lei aponta a pouca efetividade dos mecanismos de controle que deveriam verificar e punir as práticas ilícitas dos funcionários régios. Residências e devassas pouco conseguiam apesar do notório envolvimento dos implicados em negócios proibidos. A lentidão dos processos retardava a efetiva aplicação da pena, e muitos deles, ao cabo de caras e demoradas rodadas, nas quais muito papel era preenchido, selado, lido, devolvido, corrigido e reapresentado, terminavam com a nãoculpabilização do acusado. Era quase certo que um desembargador, por exemplo, não seria aprisionado e que os processos abertos contra ele não redundariam em culpa formada. Mas, por outro lado, funcionários mais modestos ou que fossem proprietários de cargos que a Coroa considerava fundamental recuperar podiam passar meses, mesmo anos, encarcerados, enquanto o processo se arrastava. De fato, a morosidade do processo permitia à Coroa pôr em prática uma das suas estratégias simbólicas de afirmação de poder, a concessão da graça real, perdoando o acusado e restituindo-lhes os bens, mas não a jurisdição, posto que, mesmo não sendo culpado formalmente, nunca mais era propriamente considerado inocente, tornando-se inadequado para o exercício da função. Em alguns casos, a morte na cadeia encerrava o assunto. Ao fim, a Coroa conseguia seu objetivo, rematando o processo com uma reforma que incorporava aquela jurisdição aos poderes de outro funcionário ou criando uma nova, com poderes ampliados. Ao invés de desgastar-se com a constante prosecução de seus representantes, o sofrimento de um bastava para servir como exemplo, lembrando a todos as consequiências do desagrado real. Para o restante dos casos, a virtualidade da aplicação da pena bastava (HESPANHA, 1993b; PJINING, 1997, p. 248-249).

A atuação de um funcionário régio dependia da rede de relações na qual se inseria. Por sua vez, esta rede era apenas uma dentre as muitas que compunham o espaço de interação social em meio à qual exercia as suas prerrogativas e que incluíam personagens situados a centenas de quilômetros de distância. Ao mesmo tempo em que auferia ganhos materiais ou simbólicos do exercício de sua função, tal funcionário via-se obrigado a constantemente adaptar-se a novas 
configurações, passíveis de questionar o alcance de seus poderes. Certa mobilidade estratégica podia ser necessária, segundo as circunstâncias, de modo a sobreviver às mudanças nas correlações de força. Não importando se fosse um simples meirinho ou o Provedor-mor. Tais mudanças dependiam de fatores que muitas vezes não controlava, embora suas ações pudessem fazer parte dos eventos que contribuíssem para a mesma. Os impasses gerados pela disputa pelas rendas resultavam em repercussões de âmbitos bastante alargados, alcançando, eventualmente, dimensões condizentes com a extensão de um império.

\section{CONSIDERAÇÕES FINAIS}

Por que enfatizar o papel da escala e a importância dos contextos de interação, particularmente no caso das redes de clientela? Que contribuição pode trazer para uma melhor compreensão dos processos sócio-históricos e, conseqüentemente, para um debate mais frutífero entre historiadores e sociólogos?

Como adiantamos na "Introdução", essa relação tem-se dado principalmente no campo da Sociologia Histórica, e nesse caso tem sido levada a cabo por sociólogos que se apropriam da literatura propriamente historiográfica para a consecução de modelos que ajudem a entender transformações de longa duração em chave comparada. Apesar das contribuições relevantes que autores como Norbert Elias, Barrington Moore, Charles Tilly ou Theda Skocpol aportaram ao estudo desses processos, a ênfase dada na linearidade implícita no resultado já conhecido a ser explicado (civilização, democracia, Estado moderno ou revolução) termina por deixar intocada uma questão de grande importância: a da diversidade de expectativas e objetivos dos agentes envolvidos e das estratégias postas em prática em contextos cujos horizontes eram definidos por representações bastante mutáveis quanto à legitimidade de uns e outros. $\mathrm{Ou}$, em outros termos, o da intencionalidade dos agentes, que termina por se confundir com a do processo. A abordagem "macro" desloca os primeiros em favor do último, relegando-os para a sombra da história, ao invés de incorporá-los como elementos constituintes do próprio processo, que perderia assim sua natureza necessária, dando espaço às ações pontuais - sempre intencionais, mas não no que diz respeito ao resultado final para o qual terminaram contribuindo. $\mathrm{O}$ texto procurou, desse modo, enfatizar a grande diversidade de combinações que só adquirem sentido quando inseridos em contextos históricos singulares dos quais não podem ser dissociados para a compreensão tanto das escolhas e ações envolvidas quanto do seu resultado. E como defendido, mais de uma ou duas variáveis ou dimensões devem ser levadas em conta para evitar o anacronismo de supor que tais agentes tinham realmente em vista objetivos que na verdade lhes foram imputados pelos modelos de análise.

Quando, por exemplo, a nobreza portuguesa procura reafirmar sua posição frente à Coroa nos séculos XV e XVI, ela recorre a uma diversidade de práticas e estratégias que constituem simultaneamente representações quanto à legitimidade das mesmas. Essas escolhas, contudo, só podem ser entendidas nos contextos de interação nas quais se dão, e é na constante atualização das configurações constituídas pelas relações entre indivíduos e grupos que se pode definir as linhas de fratura que demarcam o conflito. Uma oposição entre nobreza e letrados, dessa maneira, peca por formalismo, já que elementos da nobreza recorrem a práticas letradas para garantir suas posições frente a concorrentes à medida que constituem estratégias de representação. Tais categorias - letrados ou nobres - não podem ser pensadas dissociadas desses conflitos e composições, e supor que constituem categorias estanques empobrece a compreensão dos processos nos quais os agentes vêemse envolvidos e definem-se. Além disso, a manipulação de representações diferenciadas por agentes em situação social semelhante nem sempre significa que estamos perante dois grupos sociais distintos, mas sim que aquelas representações prestam-se à reconfiguração das relações entre seus componentes, sem definir nenhuma mudança qualitativa na sua composição social. Nesse caso, as oposições identitárias têm caráter pontual e os limites que traçam podem ser rapidamente deslocados.

Por outro lado, os agentes podem optar por um leque bastante diversificado de escolhas estratégicas, que passam eventualmente pela marginalidade, mas que, segundo a correta manipulação de representações e relações, pode constituir-se num segundo momento em condição para legitimação e ascensão social. Ser comerciante numa sociedade senhorial nem sempre significava demérito, segundo a inserção social dos indivíduos em redes múltiplas de proteção, sociedade e parentesco. Por outro lado, optar - num dado momento 
- por escapar dos limites oficiais (como no caso dos aventureiros portugueses na Índia), não significava nem uma negação da legitimidade daqueles parâmetros de avaliação social, nem a impossibilidade de um eventual retorno aos mesmos. Tudo dependeria da capacidade de manipular adequadamente - ou forjar a partir dos já existentes - os critérios de legitimação social, como à época poderiam ser o do serviço do Rei. Práticas que por um lado poderiam ser vistas como espúrias, por outro podiam ser apresentadas à luz daquele serviço: os circuitos nos quais são moldadas e filtradas - e portanto a singularidade própria a cada um deles - são tão importantes quanto as representações que aportam, por si só insuficientes para explicar o sucesso de uns e o fracasso de outros.

É a conjunção de representações culturais, organização jurídico-político e interação social que permite delimitar campos circunscritos de atuação constituídos pelos próprios agentes. Esses sempre sabem o que estão fazendo, embora possam não estar conscientes das implicações das suas ações: exatamente porque não agem independentes de contextos interacionais é que podem moldar, mas cuja conformação não têm condições de determinar. E muito menos os resultados incidentais das configurações - voltamos a repetir, singulares e fortuitas, que surgem como resultado de sua interação. Não fazer a história que se quer, neste caso, não significa não fazer história alguma, e mesmo aquelas ações que aparentemente não se encaixam no "sentido" tomado pelo processo participam da forma final resultante. Aponta-se, portanto, não só para a intencionalidade das ações, mas para a aleatoriedade dos resultados, precaução embotada por dicotomias modelares como centroperiferia, resistência-inclusão, nacional-regional e outras metáforas que delimitam posições, mas suprimem interações que as extrapolam.

Assim, para retomar o fio da exposição, o Império Português - como exemplo de qualquer outra organização sócio-espacial - é pensado como organizado em torno de um centro - a Metrópole - e uma periferia - a Colônia. Tal disposição facultaria ao analista pré-determinar a natureza de determinados conflitos (e identidades envolvidas), garantindo assim uma linearidade que culminaria - durante a primeira metade do século XIX - com a constituição de uma nova entidade a Nação-desdobrada daquela organização. Haveria colonos e colonizados, eventualmente comercian- tes e funcionários régios, de um lado, senhores de engenho e lavradores de outro. Atente-se, contudo, que tais identidades eram apenas algumas dentre as disponíveis. Laços de parentesco, relações pessoais de caráter clientelístico, interesses políticos podiam atravessar os espaços circunscritos locais, nem sempre se respeitando o eixo centro-periferia, que de qualquer modo pouco sentido fazia numa sociedade marcada por antagonismos diversos em torno de identidades corporativas e cujos critérios hierárquicos embora sempre vigentes - eram múltiplos. Conflitos de interesse apenas local podiam mobilizar grupos em Lisboa. Conflitos em Lisboa podiam repercutir localmente. Para se obter um pequeno cargo, eventualmente devia-se contar com o beneplácito de pessoas localizadas nos órgãos centrais. Para um funcionário graduado alcançar seus objetivos, a mobilização do apoio e recursos locais era imprescindível. O confronto de interesses entre a Coroa - entendida apenas como mais um dos agentes -, e os demais envolvidos, demandava mais negociação do que imposição, e isso pela própria lógica de legitimação do poder régio. A concentração de esferas de jurisdição nas mãos da Coroa, entendida como um processo de "centralização" contínuo e linear, podia depender em muito maior grau de configurações locais e fortuitas do que da iniciativa ou intenções da Coroa. Por outro lado, tal intervenção régia, embora eventualmente resultando em maior espaço de manobra por parte da Coroa, marcava apenas um deslocamento dos equilíbrios, e não a supressão definitiva de pólos alternativos já constituídos, formais ou não.

A contínua centralização do poder - tendencialmente homogênea para a totalidade de um dado território - é identificada como o processo de formação do Estado moderno. A partir de certo momento, esse processo foi igualmente um projeto, seja na Europa, seja alhures. No Brasil, essa tem sido a chave de leitura mais convencional. Contudo, apenas recentemente tem-se dado maior atenção da parte dos historiadores aos conflitos que marcaram a representação que os mais diferentes grupos davam - em momentos diferentes - a tal processo. Adicionando novos arsenais identitários em detrimento de outros, combinando-os e deslocando seu sentido, ou apropriando-se de maneiras distintas dos novos aparatos jurídicos-políticos implementados de cima para baixo, ainda aqui o resultado aparentemente 
linear apresentou contradições, hesitações, desvios e arranjos de compromisso que ao fim terminaram por determinar não só o ritmo, mas também a natureza do resultado final. Do Império Português ao Império do Brasil e à constituição do Estado federativo, a gama de agentes envolvidos e a forma como se auto-definiam em relação aos conflitos gerados por aquele processo foi mais rica do que se supõe e seu inventário apenas recentemente começou a ser feito. As heranças legadas de uma ponta a outra não pesaram apenas como fardo sobre os vivos, mas também compuseram alternativas constantemente Reinterpretadas segundo os contextos de interação que não se resumem a espaços estanques (como centro-periferia) nem a identidades atribuídas por terceiros ( $v . g$. elite-povo, branco-negro, rico-pobre). As redes de clientela constituíram uma dessas formas de interação. Em sociedades do Antigo Regime, eram de fato uma das mais importantes, e casavam-se perfeitamente com a concepção hierarquizada e conflituosa daquela sociedade, contribuindo - em certa medida - para sua própria transformação. Em outros contextos seu papel poderá ser menor - mais um recurso entre outros agora disponíveis. Mas resta - sem supor a necessidade de tal mudança mapear essa passagem, e quem sabe questionála. Afinal, nossas idéias podem ainda estar "fora do lugar" e corre-se o risco de assim mantê-las ao não se atentar para os encadeamentos (e configurações) singulares, seja no tempo, seja no espaço, que as compuseram.

Recebido para publicação em 17 de julho de 2001. Artigo aprovado em 21 de novembro de 2001.

Edval de Souza Barros (souzabarros@yahoo.com) é Mestre em História Social pela Universidade Federal Fluminense (UFF) e doutorando em História na Universidade Federal do Rio de Janeiro (UFRJ).

\section{REFERÊNCIAS BIBLIOGRÁFICAS}

ANDRIEN, K. 1982. The Sale of Fiscal Offices and the Decline of Royal Authority In the Viceroyalty of Peru, 1633-1700. HispanicAmerican Historical Review, Durham, v. 62, n. 1, p. 49-71, Feb.

BEIK, W. 1985. Absolutism and Society in Seven teenth Century France: State Power and Provincial Aristocracy in Languedoc. Cambridge : Cambridge University Press.

BETHENCOURT, F. 1998. O estado da Índia. In : BETHENCOURT, F. \& CHAUDURI, K. (orgs.). História da expansão portuguesa : do Índico ao Atlântico (1570-1697). Lisboa : Círculo de Leitores.

BONNEY, R. (ed.). 1995. Economic Systems and State Finance. Oxford : Clarendon Press.

(ed.). 1999. The Rise of Fiscal State in Europe, c. 1200-1815. Oxford: Oxford University Press.

BOXER, C. 1973. Salvador de Sá e a luta pelo Brasil e Angola (1602-1686). São Paulo : Nacional.

1981. O Império Colonial Português (1415-1825). Lisboa : Edições 70.
BOYAJIAN, J. C. 1993. Portuguese Trade in Asia under the Habsburgs (1580-1640). Baltimore and London: The John Hopkins University Press.

BREWER, J. 1989. The Sinews of Power : War, Money and the English State (1688-1783). London : Routledge.

CARDIM, P. 1998. Cortes e cultura política no Portugal do Antigo Regime. Lisboa : Cosmos.

CERRUTI, S. 1995. Normes et pratiques, ou de la légitimité de leur opposition. In : LEPETIT, B. (dir.). Les formes de l'expérience : une autre histoire sociale. Paris : Albin Michel.

1998. Processo e experiência : indivíduos, grupos e identidades em Turim no século XVII. In : REVEL, J. (org.). Jogos de escalas : a experiência da microanálise. Rio de Janeiro : Fundação Getúlio Vargas.

COATES, T. J. 1998. Degredados e órfãs : colonização dirigida pela Coroa no Império Português (1550-1750). Lisboa : Comissão Nacional para as Comemorações dos Descobrimentos Portugueses.

CUNHA, M. S. \& MONTEIRO, N. G. 1995. Vice-reis, governadores e conselheiros de gover- 
no do estado da Índia (1505-1834). Recrutamento e caracterização social. Penélope : fazer e desfazer a história, Lisboa, n. 16, p. 91-120, abr.

CURTO, D. R. 1993. A cultura política. In : MAGALHÃES, J. R. (coord.). História de Portugal : o alvorecer da modernidade (14801620). Lisboa : Estampa.

. 1998. A literatura e o Império : entre o espírito cavaleiroso, as trocas da Corte e o humanismo cívico. In : BETHENCOURT, F. \& CHAUDURI, K. (dir.). História da expansão portuguesa : a formação do Império (14151570). Lisboa : Círculo de Leitores.

DOWNING, B. 1992. The Military Revolution and Political Change : Origins of Democracy and Autocracy in Early Modern Europe. Princenton : Princenton University Press.

DUMONT, L. 1985. O individualismo : uma perspectiva antropológica da ideologia moderna. Rio de Janeiro : Rocco.

EISENSTADT, S. N. \& RONIGER, L. 1980. Patron-Client Relations as a Model of Structuring Social Exchange. Comparative Studies of Society and History, Cambridge, v. 22, n. 1, p. 42-77, Jan.

ELIAS, N. 1993. O processo civilizador. Rio de Janeiro : Jorge Zahar.

1995. A sociedade de Corte. $2^{\mathrm{a}}$ ed. Lisboa : Estampa.

EMIRBAYER, M. \& GOODWIN, J. 1994. Network Analysis, Culture, and the Problem of Agency. American Journal of Sociology, Chicago, v. 99, n. 6, p. 1411-1454, May.

ERTMAN, T. 1997. Birth of Leviathan: Bulding States and Regimes in Medieval and Early Modern Europe. Cambridge : Cambridge University Press.

GEERTZ, C. 1991. Negara: O Estado-teatro no século XIX. Lisboa : Difel.

GELLNER, E. 1988. Plough, Sword and Book: The Structure of Human History. Chicago : The University of Chicago Press.

GENET, J.-P. 1992. Introduction : Which State Rises? Historical Research, London, v. 65, n. 157, p. 119-133, Jun.
1997. La genèse de l'État moderne : les enjeux d'un programme de recherche. Actes de la Recherche en Sciences Sociales, Paris, n. 118 , p. 3-18, juin.

GOUVEIA, A. C. 1993. Estratégias de interiorização da disciplina. In : HESPANHA, A. M. (coord.). História de Portugal : o Antigo Regime (1620-1807). Lisboa : Estampa.

GRAHAM, R. 1997. Clientelismo e política no Brasil do século XIX. Rio de Janeiro : UFRJ.

HERMANN, J. 1998. No Reino do Desejado : A construção do sebastianismo em Portugal, séculos XVI e XVII. São Paulo : Companhia das Letras.

HESPANHA, A. M. 1984. Para uma teoria institucional do Antigo Regime. In : . (ed.). Poder e instituições no Antigo Regime: colectânea de textos. Lisboa : Fundação Calouste Gulbenkian.

1993a. A nobreza nos tratados jurídicos dos séculos XVI a XVII. Penélope : fazer e desfazer história, Lisboa, n. 12, p. 27-42, dez.

.1993b. Da Iustitia à disciplina : textos, poder e política penal no Antigo Regime. In : . (ed.). Justiça e litigiosidade : história e prospectiva. Lisboa : Fundação Calouste Gulbenkian.

. 1994. As vésperas do Leviathan : instituições e poder político em Portugal - século XVII. Coimbra : Almedina.

KANTOROWICZ, E. 1998. Os dois corpos do Rei. São Paulo : Companhia das Letras.

LEVI, G. 1989. Le pouvoir au village : histoire d'un exorciste dans le Piémont du XVIIe siècle. Paris : Gallimard.

LEWIN, L. 1993. Política e parentela na Paraí$b a$ : um estudo de caso da oligarquia de base familiar. Rio de Janeiro : Record.

LOUREIRO, F. S. 1989. A alteração das coordenadas da política de expansão portuguesa na segunda metade do século XVI. In : Actas das Primeiras jornadas de história moderna. Lisboa : Centro de História da Universidade de Lisboa, v. 1.

MAUSS, M. 1974. Sociologia e Antropologia. v. 2. São Paulo : Edusp/EPU. 
MELLO, E. C. 1998a. Olinda restaurada : guerra e açúcar no Nordeste, 1630-1654. 2a ed. Rio de Janeiro : Topbooks.

1998b. O negócio do Brasil : Portugal, os Países Baixos e o Nordeste, 1641-1669. Rio de Janeiro : Topbooks.

MILLÁN, J. M. 1994. Los estudios sobre la Corte : interpretación de la Corte de Felipe II. In : . (dir.). La Corte de Felipe II. Madri : Alianza.

MONTEIRO, N. G. 1998. O crepúsculo dos grandes (1750-1832) : a casa e o patrimônio da aristocracia em Portugal. Lisboa : Imprensa Nacional/Casa da Moeda.

MOORE JR., B. 1983. Origens sociais da ditadura e da democracia : senhores e camponeses na construção do mundo moderno. São Paulo : Martins Fontes.

MOUTOUKIAS, Z. 1988. Power, Corruption, and Commerce : The Making Of the Local Administrative Structure in Seventeenth-Century Buenos Aires. Hispanic-American Historical Review, Durham, v. 68, n. 4, p. 771-801, Nov.

NOVAIS, F. A. 1986. Portugal e Brasil na crise do antigo sistema colonial (1777-1808). $4^{\mathrm{a}}$ ed. São Paulo : Hucitec.

PARKER, G. 1996. The Military Revolution : Military Innovation and the Rise of the West, 1500-1800. $2^{a}$ ed. Cambridge : Cambridge University Press.

PJINING, E. 1997. Controlling Contraband: Mentality, Economy and Society in Eighteenth Rio de Janeiro. Tese (Doutorado em História). Baltimore : Johns Hopkins University.

POLANYI, K. 1980. A grande transformação : as origens da nossa época. $3^{\text {a }}$ ed. Rio de Janeiro : Campus.

REVEL, J. 1989. L'histoire au rés du soil. In : LEVI, G. Le pouvoir au village : histoire d'un exorciste dans le Piémont du XVIIe siècle. Paris : Gallimard.

1998. Microanálise e construção do social. In : . (org.). Jogos de escalas : a experiência da microanálise. Rio de Janeiro : Fundação Getúlio Vargas.

SCHAUB, J.-F. 1995. Le temps et l'État : vers un noveau régime historiographique de l'ancien régime français. Quaderni Fiorentinni, Firenze, n. 25, p.127-181.

SCHWARTZ, S. 1979. Burocracia e sociedade no Brasil colonial : a Suprema Corte da Bahia e seus juízes (1609-1751). São Paulo : Perspectiva.

SKOCPOL, T. (org.). 1984. Vision and Method in Historical Sociology. Cambridge : Cambridge University Press.

.1985. Estados e revoluções sociais : análise comparativa da França, Rússia e China. Lisboa : Presença.

SUBRAHMANYAM, S. 1994. Comércio e conflito : a presença portuguesa no Golfo de Benguala, 1500-1700. Lisboa : Edições 70.

T'HART, M. C. 1993. The Making of the Bourgeois State : War, Politics and Finance during the Dutch Revolt. Manchester : Manchester University Press.

THOMAZ, L. F. 1994. De Ceuta a Timor. Lisboa : Difel.

TILLY, C. 1996. Coerção, capital e Estados europeus. São Paulo : Edusp.

TURNER, V. 1988. A Theory of Social Interaction. Stanford : Stanford University Press.

WEBER, M. 1998. Economia e sociedade. Brasília : Edunb.

XAVIER, A. B. \& HESPANHA, A. M. 1993. As redes clientelares. In : HESPANHA, A. M. (coord.). História de Portugal : o Antigo Regime (1620-1807). Lisboa : Estampa. 